\title{
Recent innovation in microbial source tracking using bacterial real-time PCR markers in shellfish
}

\author{
A. Mauffret, S. Mieszkin, M. Morizur, Y. Alfiansah, S. Lozach, M. Gourmelon* \\ IFREMER, Laboratoire de Microbiologie, RBE, EMP, Plouzané, France \\ *: Corresponding author : Michèle Gourmelon, tel.: +33298224576 ; fax: +33298224594 ; \\ email address : Michele.Gourmelon@ifremer.fr
}

\begin{abstract}
:
We assessed the capacity of real-time PCR markers to identify the origin of contamination in shellfish. Oyster, cockles or clams were either contaminated with fecal materials and host-associated markers designed from Bacteroidales or Catellicoccus marimammalium 16S RNA genes were extracted from their intravalvular liquid, digestive tissues or shellfish flesh. Extraction of bacterial DNA from the oyster intravalvular liquid with FastDNA spin kit for soil enabled the selected markers to be quantified in $100 \%$ of artificially contaminated samples, and the source of contamination to be identified in 13 out of 38 naturally contaminated batches from European Class B and Class C areas. However, this protocol did not enable the origin of the contamination to be identified in cockle or clam samples. Although results are promising for extracts from intravalvular liquid in oyster, it is unlikely that a single protocol could be the best across all bacterial markers and types of shellfish.
\end{abstract}

\section{Highlights}

DNA extraction from intravalvular liquid is promising for microbial source tracking in oysters. Host-associated bacterial markers in shellfish digestive tissues were difficult to assess with real-time PCR. DNA extracts from shellfish flesh appeared to have low inhibitor levels but low marker levels. - Protocol transfer from one shellfish species to another does not appear possible.

Keywords: Microbial source tracking ; Shellfish ; Bacteroidales ; Real-time PCR ; Intravalvular liquid ; Digestive tissues 


\section{Introduction}

Shellfish contamination by fecal waste may lead to disease outbreaks among shellfish consumers. For example, Salmonella spp. and enteric viruses were identified as the pathogenic agents responsible for 12 and 63 disease outbreaks, respectively, out of the 195 linked to shellfish consumption that were reported to French health authorities between 2006 and 2008 (Delmas et al., 2010). The European Union, under Regulation (EC) No. 854/2004 (2004), designed a classification system to determine whether a shellfish harvesting area was sufficiently clean to be used and, if so, what level of treatment should be applied to harvested shellfish prior their sale for consumption. This classification system is based on Escherichia coli monitoring in total shellfish flesh (SF): shellfish in Class A areas have $<230$ E. coli $100 \mathrm{~g}^{-1} \mathrm{SF}$ in $100 \%$ of samples and can be harvested for direct human consumption; shellfish in Class B areas have $<4,600 \mathrm{E}$. coli $100 \mathrm{~g} \mathrm{~g}^{-1} \mathrm{SF}$ in $90 \%$ of samples and are only suitable for human consumption after depuration, relaying or cooking by an approved method; shellfish in Class C areas have $<46,000 \mathrm{E}$. coli $100 \mathrm{~g}^{-1} \mathrm{SF}$ in $100 \%$ of the samples and can only be consumed after relaying for at least 2 months or cooking by an approved method; finally, when the 46,000 MPN E. coli $100 \mathrm{~g}^{-1}$ SF limit is exceeded, shellfish are considered unfit for human consumption and such areas are closed for harvesting. In addition to the standardized $E$. coli classification, the use of microbial source tracking to identify the origin of fecal contamination as human, livestock or wildlife would vastly improve shellfish quality management and help plan measures to reduce such pollution.

Host-associated markers targeting viral RNA or mitochondrial DNA genes have been used to trace sources of fecal contamination in shellfish (Baker-Austin et al., 2010; Ley et al., 2002; Pina et al., 1998; Wolf et al., 2010). One major limitation of both these approaches is their low marker sensitivity. Markers were typically detected at levels close to the limit of detection even though studies were performed on shellfish that were highly contaminated (either artificially or naturally). In addition, lack of specificity of several viral genogroups, such as the F-specific RNA bacteriophage genogroups or adenoviruses (Mauffret et al., 2012; Wolf et al., 2010), and seasonal prevalence of viral markers, such as hepatitis A virus and enterovirus (Pina et al., 1998), has impeded their use as routine MST markers. A few other studies have reported the application of host-associated bacterial markers to shellfish; these considered the use of human-associated $E$. coli, and animaland human-associated markers in enterococci in mussels (Roslev et al., 2010; Roslev et al., 2009).

Host-associated markers based on 16S RNA gene sequences of Bacteroidales, a major bacterial group of mammal gut flora, provide a large panel of host-associated markers with high sensitivity and specificity (Mieszkin et al., 2009a; Mieszkin et al., 2009b; Mieszkin et al., 2010; Seurinck et al., 2005). Host-associated Bacteroidales markers have also proven their capacity to identify the origin of fecal contamination in environmental waters (Gourmelon et al., 2010; Reischer et al., 2008; Shanks et al., 2006). The Gull2 marker, which targets 16S RNA gene sequences closely related to C. marimammalium (C. marimammalium), appeared useful for tracing coastal bird fecal contamination (Lu et al., 2008). To the best of our knowledge, the use of such promising real-time PCR markers in shellfish has not been reported to date, probably due to technical challenges of extracting bacterial DNA from shellfish samples in sufficient amounts to be directly quantified. To counter this limitation, protocols typically include a bacterial culturing step prior to analysis of molecular bacterial markers in shellfish (Nordstrom et al., 2007; Panicker et al., 2004; Roslev et al., 2010; Roslev et al., 2009; Vantarakis et al., 2000). However, Bacteroidales strains, because they are strict anaerobic bacteria, only survive for a short time in aerobic conditions and are difficult to cultivate (Ballesté and Blanch, 2010; Savichtcheva et al., 2005).

Viral and bacterial PCR markers are usually monitored in total shellfish flesh (Nordstrom et al., 2007; Panicker et al., 2004; Pina et al., 1998; Roslev et al., 2009; Vantarakis et al., 2000), or digestive tissues (Gourmelon et al., 2006; Le Guyader et al., 2008; Lowther et al., 2008; Wolf et al., 2010). Digestive tissues are believed to be the compartment of shellfish in which bacteria and viruses from the surrounding water are the most concentrated (Dore and Lees, 1995; Maalouf et al., 2010; Wang et al., 2010). In addition, the liquid found within the shell next to the shellfish flesh, the "intravalvular liquid", has been proposed as a potentially promising matrix for real-time PCR 
quantification of Vibrio parahaemolyticus in oysters, because it seemed to contain less inhibition of PCR amplification than with the use of homogenized oyster tissue (Kaufman et al., 2004). In addition, since it is a liquid sample, like water, we hypothesized that it might also be a relevant target for real-time PCR analysis of the same bacterial markers that perform well on environmental water samples. The present paper brings together work done on protocol development since 2009, through a selection of experiments aiming to select promising protocol(s) to trace the origin of the fecal contamination in shellfish using host-associated Bacteroidales and $C$. marimammalium markers.

\section{Materials and methods}

\subsection{Experimental design}

The experimental design included three steps: (i) we initially focused on bacterial DNA extraction from digestive tissues by testing four DNA extraction kits on digestive tissues from artificially contaminated oysters (experiment 1); (ii) we then considered additional tissues from artificially contaminated oysters, using one DNA extraction kit for each tissue: DNA was extracted from digestive tissues with DNAZOL, from intravalvular fluid with FastDNA or from total shellfish flesh with DNAZOL (experiments 1-4); and (iii) we extended the assays to naturally contaminated shellfish: oysters, cockles or clams (Table 1). A protocol was defined as a combination of one shellfish compartment and one bacterial DNA extraction kit (e.g., intravalvular liquid-FastDNA).

\subsection{Shellfish contamination}

Both artificially and naturally contaminated shellfish were tested. Live oysters (Crassostrea gigas) used for the artificially contaminated experiments were purchased from a local farm where they were being sold for human consumption. These oysters were acclimated for $48 \mathrm{~h}$ in an aerated $50-$ $L$ tank with $2-\mu \mathrm{m}$ filtered natural seawater (300 $\mathrm{mL}$ seawater per oyster). Then, either fecal material or a pure bacterial strain was added to the seawater at the following nominal concentrations: pig

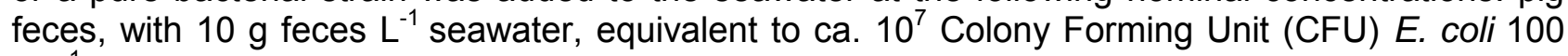
$\mathrm{mL}^{-1}$ seawater (experiment 1); waste water treatment plant influent (WWTP), with $100 \mathrm{~mL}$ influent $\mathrm{L}^{-1}$ seawater, equivalent to ca. $10^{5} \mathrm{CFU}$ E. coli $100 \mathrm{~mL}^{-1}$ seawater (experiment 2); cow pat, with 10 $\mathrm{g}$ feces $\mathrm{L}^{-1}$ seawater, equivalent to $10^{6} \mathrm{CFU}$ E. coli $100 \mathrm{~mL}^{-1}$ seawater (experiment 3 ); and $C$. marimammalium, with $10^{7} \mathrm{CFU} 100 \mathrm{~mL}^{-1}$ seawater (experiment 4) (Table 1). One contaminated microcosm was set up for each experiment, together with one control microcosm with 2- $\mu \mathrm{m}$ filtered natural seawater and oysters at the same density. Oysters were removed from the tanks for analysis after 24-h (experiments 2, 3 and 4) or 72-h (experiment 1) exposure.

Naturally contaminated oysters (Crassostrea gigas), cockles (Cerastoderma edule) and clams (Tapes spp) were collected at low tide at different sites on the west and Mediterranean coasts of France between 2009 and 2011 ( $n=38$ sites for oysters and $n=22$ sites for cockles and clams). These sites were selected for their particularly high exposure to fecal contamination, either from animal or human origin; E. coli indeed exceeded $230 \mathrm{E}$. coli $100 \mathrm{~g}^{-1} \mathrm{SF}$ (class B level) in the naturally contaminated shellfish (Table 2 ).

\subsection{Feces samples, bacterial strains and bacterial enumeration}

Freshly collected pig feces and cow pat samples were obtained from local farmers, and WWTP influent from a local plant. Feces and influent samples were conserved at $4^{\circ} \mathrm{C}$ and processed within $24 \mathrm{~h}$ of collection.

E. coli cells in feces, influent and artificially contaminated seawater samples were enumerated by plating onto Tryptone Bile X-Glucuronide medium (TBX, Oxoid) and incubating at $44^{\circ} \mathrm{C}$ for $24 \mathrm{~h}$. $E$. 
coli concentrations in shellfish were assessed using the five-tube Most Probable Number (MPN) method [NF EN ISO 16649-3 (ISO, 2005)].

To prepare the bacterial inoculum for use in experiment 4, C. marimammalium strain M35/04/3T, previously isolated from a dead porpoise by Lawson et al. (2006), was grown in Columbia broth (Difco) with $10 \%$ bile (Sigma) at $37^{\circ} \mathrm{C}$ for $24 \mathrm{~h}$ in aerobic and static conditions. The cells were harvested by centrifuging the cultures, washed twice with phosphate buffered saline (PBS) and, finally, resuspended in the natural seawater of the same type as that used in the microcosm. $C$. marimammalium cells were isolated or enumerated on sheep blood agar after $48 \mathrm{~h}$ incubation at $37^{\circ} \mathrm{C}$ (Lawson et al., 2006).

The limit of quantification of the bacterial numeration by culture was $10(1 \mathrm{log})$ Colony Forming Units (CFU) $100 \mathrm{~mL}^{-1}$ seawater or $15\left(1.18 \mathrm{log}\right.$ ) Most Probable Number (MPN) $100 \mathrm{~g}^{-1} \mathrm{SF}$.

\subsection{Sample collection for real-time PCR marker analyses}

Within $24 \mathrm{~h}$ of their collection from the microcosm or field, the shellfish were washed externally under running tap water, opened aseptically, dissected and homogenized as described below. During the dissection step, both shellfish and tissue samples were kept on ice or at $4^{\circ} \mathrm{C}$. Samples consisted of aliquots of a single homogenized tissue or intravalvular liquid from 12 oysters, 30 cockles or 30 clams per batch. Specific details for tissues and species are as follows.

Intravalvular liquid (IL) was collected, placed in a Falcon tube $(15 \mathrm{~mL})$ and centrifuged at $2500 \mathrm{~g}$ for $15 \mathrm{~min}$. The supernatant was discarded and the pellet stored at $-80^{\circ} \mathrm{C}$ until bacterial DNA extraction.

Digestive tissues (DT) were dissected from the shellfish flesh, and either i) manually homogenized with a scalpel, aliquoted (300 mg equivalent digestive tissue) and stored at $-80^{\circ} \mathrm{C}$ until DNA extraction (experiment 1; 18 oyster batches sampled from the field) or ii) manually homogenized with a scalpel, aliquoted $(4 \mathrm{~g})$ in $50 \mathrm{~mL}$ Falcon tubes, stored at $-80^{\circ} \mathrm{C}$, and then homogenized with a Polytron $3 \times 30 \mathrm{~s}$ (Kinemetica AG, Switzerland) in PBS at a digestive tissue weight $(\mathrm{g}): \mathrm{PBS}(\mathrm{mL})$ ratio of 1:1, just before DNA extraction (experiments 2-4; 6 oyster batches and 26 cockle or clam batches sampled from the field). The homogenate was allowed to settle for $15 \mathrm{~min}$ and the supernatant (250-500 $\mu \mathrm{L})$ was used for DNA extraction. No statistical difference was observed between the two sample preparation methods (i and ii). AllBac levels were indeed similar between the samples manually or mechanically homogenized (Student test: $P=0.18$ ); these samples had similar E. coli levels $(P=0.68)$.

Total shellfish flesh, including shellfish flesh and intravalvular liquid (SF, $100 \mathrm{~g}$ ), was homogenized in a commercial blender system (Warring Products Division, CT, USA), $3 \times 30 \mathrm{~s}$ with saline peptone water [SPW; 0.1\% Bacto Peptone (Becton, Dickinson and Company) and $0.85 \% \mathrm{NaCl}$ (Sigma)] at a total shellfish flesh weight $(\mathrm{g}): \mathrm{SPW}(\mathrm{mL})$ ratio of 1:2. Following a 15-min decantation, the supernatant $(15 \mathrm{~mL})$ was collected in a Falcon tube, centrifuged $(2500 \mathrm{~g}, 15 \mathrm{~min})$ and the pellet stored at $-80^{\circ} \mathrm{C}$ until DNA extraction.

Seawater was sampled from the control and artificially contaminated microcosms at the beginning (t0) and end ( $\mathrm{t}$ end) of the experiment. Samples (20-500 $\mathrm{mL}$ according to the turbidity) were then filtered through 0.45- $\mu \mathrm{m}$ cellulose membrane (Pall Gelman GN-6 Metricel; Pall Corporation) under sterile conditions. The filters were then vortexed with $500 \mu \mathrm{L}$ GITC [5 M guanidine, $100 \mathrm{mM}$ EDTA $(\mathrm{pH}=8.0), 0.5 \%$ Sarkosyl] and stored at $-80^{\circ} \mathrm{C}$ until DNA extraction.

\subsection{Bacterial DNA extraction}

For the artificially contaminated samples, DNA extractions were performed with at least three replicates (Table 1). For the naturally contaminated shellfish samples, one to three DNA 
extractions were performed per sample (Table 1). For all methods tested, the manufacturer's recommendations were followed, with additional modifications made to the procedures as detailed in the paragraphs below. All DNA extracts were stored at $-80^{\circ} \mathrm{C}$ until PCR.

DNA was extracted from intravalvular liquid samples using FastDNA $®$ spin kit for soil (FastDNA, MP Biomedical, Illkirch, France). An extra washing step with the salt/ethanol wash solution (SEWSM) was added to the method, as described in Dick et al. (2005).

DNA was extracted from digestive tissues samples using (i) FastDNA as described for intravalvular liquid; (ii) $\mathrm{DNAZOL}^{\circledR}$ Reagent (Invitrogen, Illkirch, France), with an additional treatment using "Iysing E matrix" tubes (MP Biomedicals, France) to enhance the homogenization step in DNAZOL (1 mL) with a FastPrep® Instrument (FP120, MP Biomedicals, France); (iii) MagMax Total Nucleic Acid Isolation Kit (MAGMAX, Applied Biosystems, Villebon sur Yvette, France); and (iv) QIAamp DNA Stool Mini Kit (STOOL, QIAGEN, Courtaboeuf, France), with the initial cell lysis and homogenization step performed at $90^{\circ} \mathrm{C}$ instead of the $70^{\circ} \mathrm{C}$ recommended by manufacturers.

DNA was extracted from total shellfish flesh using DNAZOL as described for digestive tissues.

DNA was extracted from water samples using QIAamp DNA mini kit (Mini Kit, Qiagen, Courtaboeuf, France). Two modifications were made to the method: proteinase $\mathrm{k}$ treatment was deleted and AL buffer $(700 \mu \mathrm{L})$ was added to the filter with GITC buffer.

\subsection{Real-time PCR assays}

To save time, cost and effort, host-associated real-time PCR marker concentrations were only assessed in the samples where presence of the corresponding host was expected. For instance, AllBac and Rum2Bac concentrations were assessed in the samples collected in the microcosm contaminated with cow pat, however the human-, pig- and gull-associated marker concentrations were not assessed in these samples. In the environmental samples, host-associated markers were assessed according to the main contamination expected based on our knowledge of the population and land uses in the upstream catchment. The primer and probe sequences and amplification conditions used in the present study are as described in Mieszkin et al. (2009a) for AllBac, HF183, Pig1Bac, Pig2Bac, except that Platinum ${ }^{\circledR}$ PCR SuperMix (Invitrogen) was used for the PCR assays of Pig2Bac (as in Mieszkin et al., 2010) Rum2Bac (as in Mieszkin et al., 2009b), and Hum1Bac. For Gull2, conditions were as described in Lu et al. (2008), except that Brilliant Sybr® Green QPCR Master Mix (Agilent Technologies, France) was used. TaqMan Exogenous Internal Positive Control (IPC) reagents kit (EXO IPC, Applied Biosystems, France) was added to the AllBac assays to distinguish true target negatives from PCR inhibition. The concentration of the IPC primers in the PCR assay was limiting and no competition between AllBac and the IPC reaction was observed. When PCR inhibitors were present, DNA extracts were diluted 10-, 100- or 1000 -fold to prevent them from influencing the subsequent host-associated marker PCR reactions. Controls included non-template controls, as well as filtration and DNA extraction blanks. LOQ was set at 5 copies per PCR well in triplicate PCR assays. This was the lowest quantity of linear plasmid DNA of the standard curve made for each PCR assay. The equivalent LOQ concentrations depended on the volume of sample filtered and the dilution of the DNA extract for the PCR assay.

\subsection{Protocol efficiency assessment}

Efficiency of the tested protocols, i.e., of the combinations of shellfish compartment and bacterial DNA extraction kit, was assessed according to (1) the quantification rate of the selected markers $(\% Q)$ and (2) the difference between the marker concentrations and their respective limit of quantification (Q level - LOQ). A protocol was considered efficient when (1) AllBac and the selected host-associated markers could be measured at quantifiable levels in $100 \%$ of the artificially contaminated samples, (2) AllBac could be measured at quantifiable levels in a large majority of the naturally contaminated samples that were selected from an $E$. coli contaminated 
area and (3) AllBac concentrations were about two log higher than the LOQ in the artificially or naturally contaminated samples.

\subsection{Statistics}

E. coli oyster to water ratio was determined as the ratio between $E$. coli concentrations in the total shellfish flesh (log MPN $100 \mathrm{~g}^{-1} \mathrm{SF}$ ) and in the surrounding seawater (log CFU $100 \mathrm{~mL}^{-1}$ seawater) at the end of the exposure.

Statistical analyses were performed using XLSTAT Version 2011.2.02. Values below the LOQ were set at 0 . To assess the level of association between $E$. coli and real-time PCR markers, or between the real-time PCR markers themselves, two approaches were used. Spearman coefficients were assessed. In cases where these were not significant, the variables were ranked to build contingency tables and Fisher's Exact probability were used to look for other types of associations than correlations. Thresholds were considered significant when $P<0.05$.

\section{Results}

\subsection{Artificially contaminated seawater and oyster samples}

\subsubsection{Bacterial levels in control microcosms}

E. coli and C. marimammalium cells and the host-associated real-time PCR markers Pig1Bac, Rum2Bac, HF183 and Gull2 were not detected in seawater or oyster samples from the control microcosms. AllBac was also not detected in digestive tissues or total shellfish flesh samples. AllBac was, however, quantified at low levels in control samples of seawater and intravalvular liquid.

\subsubsection{Bacterial level stability in seawater from contaminated microcosms}

In the pig feces, WWTP influent and cow pat microcosms, initial E. coli concentrations were 7.1, 5.8 and $4.3 \log$ CFU $100 \mathrm{~mL}^{-1}$ seawater (Figure 1), respectively, and initial AllBac concentrations ranged from 8.5 to 9.4 log copies $100 \mathrm{~mL}^{-1}$ seawater (Figure 2). AllBac concentrations were 3.4-4.8 log copies $100 \mathrm{~mL}^{-1}$ seawater higher in the contaminated microcosms than in the control microcosms. Initial host-associated marker concentrations (Pig1Bac, Rum2Bac, and HF183) ranged from 6.8 to $8.2 \mathrm{log}$ copies $100 \mathrm{~mL}^{-1}$ seawater, i.e., 1.2-1.5 log lower than the corresponding AllBac concentrations (Figure 2). E. coli, AllBac, and host-associated marker levels were likely to be more stable in the pig feces or cow pat microcosms than in the WWTP microcosm (Figures 1 and 2).

In the C. marimammalium microcosm, initial C. marimammalium cell concentration was 7.6 log CFU $100 \mathrm{~mL}^{-1}$ seawater and decreased by 2.0 log over $24 \mathrm{~h}$ (Figure 1). Initial Gull2 concentration was 6.8 log copies $100 \mathrm{~mL}^{-1}$ seawater and decreased by 0.9 log over $24 \mathrm{~h}$ (Figure 2).

\subsubsection{E. coli levels in oysters and oyster to water ratio}

$E$. coli concentrations of oysters used in the artificial contamination experiment were below 15 MPN $100 \mathrm{~g}^{-1} \mathrm{SF}$. As expected, E. coli was not detected in oyster samples following exposure to $C$. marimammalium. Following exposure to pig feces, WWTP influent and cow pat, $E$. coli concentrations in oysters were $>4.3,5.2$ and $4.4 \log$ MPN $100 \mathrm{~g}^{-1} \mathrm{SF}$, respectively, i.e., close to or higher than the European Class $C$ limit (Figure 1). The oyster to water ratio was consequently $>0.6,1.0$ and 1.1, in the pig feces, WWTP influent and cow pat microcosms, respectively. 


\subsubsection{Protocol efficiency}

Intravalvular liquid-FastDNA enabled real-time PCR markers, AllBac and host-associated markers, to be quantified in $100 \%$ of the samples analyzed. AllBac concentrations ranged from 4.3-5.9 log copies $\mathrm{mL}^{-1} \mathrm{IL}$, i.e., $3.0 \pm 1.5 \mathrm{log}$ copies $\mathrm{mL}^{-1} \mathrm{IL}$ higher than the LOQ (Figure 3). AllBac concentrations were 2.3-3.4 log copies $\mathrm{mL}^{-1} \mathrm{IL}$ above the concentrations measured in the control microcosms. Host-associated marker concentrations ranged from 2.0 to $5.1 \mathrm{log}$ copies $\mathrm{mL}^{-1} \mathrm{IL}$, i.e., from 0.8 to $3.5 \log$ copies $\mathrm{mL}^{-1} \mathrm{IL}$ higher than the LOQ. Host-associated markers were 1.0-2.3 log copies $\mathrm{mL}^{-1} \mathrm{IL}$ lower than the AllBac concentration in the corresponding sample.

Digestive tissues-DNAZOL enabled AllBac to be quantified in $100 \%$ of the samples, at concentrations ranging from 4.3 to $7.3 \mathrm{log}$ copies $\mathrm{g}^{-1} \mathrm{DT}$. These concentrations were closer to the LOQ than those determined with intravalvular liquid-FastDNA (Figure 3). Similarly, the hostassociated markers HF183, Rum2Bac and Pig1Bac, were less than one log higher than the LOQ, and Gull2 was not quantified. As with intravalvular liquid-FastDNA, host-associated marker concentrations were 1.2 to $2.2 \mathrm{log}$ lower than the AllBac ones. The three other kits tested, FastDNA, MAGMAX and STOOL, did not enable AllBac and Pig1Bac to be quantified in all of the extraction replicates of the artificially contaminated digestive tissue. In addition, concentrations were lower than those obtained with DNAZOL.

Although total shellfish flesh-DNAZOL enabled AllBac to be quantified in $100 \%$ of the samples at concentrations $3.0 \pm 1.3 \log$ copies $100 \mathrm{~g}^{-1} \mathrm{SF}$ higher than the LOQ, this protocol did not allow HF183 and Gull2 to be quantified in samples contaminated with WWTP influent or $C$. marimammalium, respectively (Figure 3 ).

\subsubsection{Field contaminated shellfish}

In oyster batches, mean $E$. coli concentration was $3.1 \pm 0.5 \log$ MPN $100 \mathrm{~g}^{-1} \mathrm{SF}(n=38)$ (Table 2). E. coli concentration was below the European Class A limit $\left[230\right.$ (2.36 log) MPN $\left.100 \mathrm{~g}^{-1} \mathrm{SF}\right]$ in three oyster batches; between Class A and B limits [230 and 4,600 (3.66 log) MPN $100 \mathrm{~g} \mathrm{~g}^{-1} \mathrm{SF}$ ] in 33 batches and between Class B and C limits [4,600 and 46,000 (4.66 log) E. coli $\left.100 \mathrm{~g} \mathrm{~g}^{-1} \mathrm{SF}\right]$ in two batches. Intravalvular liquid-FastDNA enabled AllBac to be quantified in $95 \%$ of the samples at $3.2 \pm 0.7$ log copies $\mathrm{mL}^{-1} \mathrm{IL}$ (min-max: $1.6-4.3$ ), which was ca. $1.6 \mathrm{log}$ higher than the LOQ (Table 2). Human-associated markers (HF183 or Hum1Bac) and the ruminant-associated marker Rum2Bac were quantified in 11 and 8 of these samples, respectively (Table 2) resulting in the identification of the contamination source as human only in five samples, ruminant only in two samples and mixed (human-ruminant) in six samples $(n=38)$. Host-associated markers were quantified in samples with $E$. coli and AllBac concentrations of $3.1 \pm 0.3$ (min-max: $2.8-3.5$ ) log MPN $100 \mathrm{~g}^{-1} \mathrm{SF}$ and $3.5 \pm 0.4$ (min-max: $2.8-4.1$ ) log copies $\mathrm{mL}^{-1} \mathrm{IL}$, respectively. However, realtime PCR Bacteroidales marker concentrations were not correlated with $E$. coli concentrations (Spearman $\mathrm{P}>0.05$ ). Fisher exact tests on the contingency table built with microbial level rankings were also not significant $(P>0.05)$. On the other hand, AllBac concentrations were found to be correlated with concentrations of the human-associated markers (HF183 and Hum1Bac) and ruminant-associated marker (Rum2Bac) (Spearman $r=0.52$ and 0.51 , respectively, $P<0.05$ ). In addition, HF183, Rum2Bac and Pig2Bac marker PCR signals were detected below the LOQ and were therefore not present at reliable concentrations in $6(n=18), 13(n=35)$ and $5(n=18)$ samples, respectively.

The two additional protocols tested, digestive tissues-DNAZOL and total shellfish flesh-DNAZOL, allowed AllBac to be quantified in a minority of samples at levels less than ca. one log above the LOQ. HF183, Rum2Bac, Pig2Bac, and Gull2 were not quantified in any oyster samples when these methods were used (Table 2).

In the field samples of burrowing shellfish, mean $E$. coli concentration was $3.4 \pm 0.7 \mathrm{MPN} 100 \mathrm{~g}^{-1}$ SF. E. coli concentrations were between Class A and B limits in 13 cockles and clams batches and between Class $B$ and $C$ limits in five batches. Finally, $E$. coli level exceeded the Class $C$ limit in two batches. E. coli was not recorded for two of the clam samples. The three protocols tested with 
cockles and clams, based on the DNA extraction from intravalvular fluid, digestive tissues and total shellfish flesh enabled AllBac to be quantified in less than $86 \%$ of samples, and only $45 \%$ when the intravalvular fluid-FastDNA method was used, even though this method appeared efficient with oysters (Table 2). AllBac levels were about one log higher than the LOQ, and host-associated markers were not quantified in the cockle and clam samples with any of the three protocols tested.

\subsection{Presence of PCR inhibitors in DNA extracts}

PCR inhibitors were detected in most of the oyster digestive tissue samples by the Internal Positive Control (IPC). These digestive tissue samples therefore needed to be diluted prior to the PCR runs to prevent these inhibitors from influencing the subsequent host-associated marker PCR reactions. PCR inhibitors were comparatively less frequent in oyster intravalvular fluid and total shellfish flesh samples, whatever the means by which these had been contaminated (artificially or naturally) (Table 3). With cockles and clams, inhibitors were detected in a majority of digestive tissues or intravalvular fluid samples but to a lesser extent in the total shellfish flesh.

\section{Discussion}

AllBac recovery rate from shellfish samples illustrated the presence of bacteria belonging to the Bacteroidales group. AllBac presence in the seawater and shellfish samples from the control experiments, where no E. coli was detected, showed that this general Bacteroidales marker might not necessarily be related to only fecal contamination, as previously suggested (Mauffret et al., 2012; van der Wielen and Medema, 2010). However, the contamination of the microcosms with fecal materials enhanced the AllBac concentrations by ca. four log above the concentrations in the control microcosm. Host-associated marker concentration fell below LOQ when AllBac was less than one log higher than the LOQ, showing that host-associated PCR runs are likely to be of no use in such cases.

The oyster to water ratios obtained in the present microcosms appeared independent of the fecal material tested, whether this was pig feces, cow pat or WWTP (from $>0.6$ to 1.1). Similar ratios were observed in previous bioaccumulation experiments (Monique Pommepuy, personal communication). In the field, Shieh et al (2003) reported higher and variable oyster (total shellfish flesh) to water ratios, ranging from 2 to 146 over a 2-year sampling period (mean: 28). A seasonal effect on the ratio has also been reported, with ratios about twice as high in warmer conditions as in colder ones (Burkhardt and Calci, 2000; Perkins et al., 1980). Differences in oyster to water ratio between microcosms in the present study and field conditions illustrate the difficulty of simulating environmental conditions in the laboratory and the high variability in filtration and bacterial uptake rate by shellfish.

The intravalvular liquid-FastDNA protocol seemed to be a promising method for tracing the source of fecal contamination in artificially and naturally contaminated oysters. AllBac, HF183 or Rum2Bac concentrations in intravalvular liquid were not correlated with $E$. coli concentrations in shellfish. However, in the field samples, the possibility that there is a source of $E$. coli other than human or ruminant contamination cannot be excluded. HF183 or Rum2Bac were not quantified in oysters with less than $2.8 \log$ MPN E. coli $100 \mathrm{~g}^{-1} \mathrm{SF}$. In cockles and clams, the intravalvular liquidFastDNA protocol did not appear relevant for tracing the source of the contamination. Intravalvular liquid of cockles or clams was technically much more difficult to pass through the Spin filter tube of the FastDNA spin kit for soil than intravalvular liquid of oysters, suggesting that these shellfish had a different intravalvular liquid composition and turbidity. Application of the intravalvular liquidFastDNA protocol to identify the source of the fecal contamination using host-associated Bacteroidales markers in oysters under contrasting environmental conditions is presently undergoing tests to validate its relevance as an MST tool (Miezkin et al., in preparation). 
Among the four extraction kits tested on digestive tissues, DNAZOL produced both the highest quantification rates and levels (Figure 3. B). Digestive tissues-DNAZOL, however, resulted in marker levels close or below LOQ and lower than the ones obtained with the intravalvular liquidFastDNA protocol (Figure 3). In contrast, viral RNA extraction from digestive tissue is a typical method with which high viral marker levels can be obtained (Le Guyader et al., 2008; Lowther et al., 2008; Wolf et al., 2010). Procedures used for viral RNA extraction allow larger sample volumes to be used: up to few grams of tissues instead of the $0.3 \mathrm{~g}$ limit of the bacterial DNA extraction kits employed in the present study. Despite its large size, the digestive gland may also account for only a small part of the total bacterial population in oysters. Very few studies have focused on the localization of enteric bacteria in shellfish tissues. Kueh and Chan (1985) reported that only $2 \%$ of the fecal coliform and $1 \%$ of the heterotrophic bacteria found in the whole oyster were present in the digestive tissues. These authors suggested that intracellular and extracellular digestion occurring in the digestive gland, as well as the presence of lysozymes, may reduce sensitive bacteria content. Enteric bacteria, such as Salmonella, were observed by immunohistochemistry in artificially contaminated oysters; they were mainly found within the gut lumen but also, to a smaller extent, in the digestive gland and within the vesicular connective tissue (Morrison et al., 2012). Localization of enteric bacteria in shellfish may help the development of microbial source tracking methodology by suggesting alternative tissues that could be used for the extraction of bacterial host-associated markers.

The limited concentration of Bacteroidales in digestive tissues might also be explained by a low DNA extraction recovery or the presence of PCR inhibitors. Inhibitors appeared present in DNA extracts even following treatments such as PVPP and/or strong mechanical cell breaking (e.g., with bead beating) (Table 3). Luan and Levin (2008) used activated carbon coated with bentonite to reduce the PCR inhibitors in the DNA extracts. They were thus able to recover E. coli 0157:H7 in total shellfish flesh of oyster without pre-enrichment, with a limit of detection of 4.7 log genomic target $100 \mathrm{~g}^{-1} \mathrm{SF}$. Such a treatment may help to decrease the limit of quantification. Additionally, increasing the PCR sensitivity may allow the samples with a signal below the LOQ to be quantified.

The protocol based on total shellfish flesh did not seem to be efficient for Bacteroidales or $C$. marimammalium DNA extraction from oysters, cockles or clams, although the level of PCR inhibitors appeared lower than in DNA samples extracted from digestive tissues.

\section{Conclusions}

Among the six protocols tested, i.e., combinations of one shellfish compartment and one bacterial DNA extraction kit, intravalvular liquid-FastDNA provided the most promising results for microbial source tracking in oyster. This protocol enabled us to determine the source of the contamination in artificially contaminated oysters, with host-associated marker levels that were one to four log higher than the limit of quantification. In addition, intravalvular liquid-FastDNA enabled us to identify human, ruminant or mixed human-ruminant contamination in 13 out of the 38 oyster batches from the field. $E$. coli concentrations in these oysters ranged from 2.8 to $3.5 \log$ MPN $E$. coli $100 \mathrm{~g}^{-1} \mathrm{SF}$. Digestive tissues did not appear to provide an adequate basis for bacterial DNA extraction with any of the four extraction kits tested under the conditions used. None of the three protocols tested with naturally contaminated cockles and clams, including intravalvular liquidFastDNA, appeared to efficiently identify human, ruminant or pig fecal contamination. It was likely that differences between shellfish species, e.g., in the composition of intravalvular fluid of oysters compared with cockles and clams, seemed to hinder protocol generalization for microbial source tracking in shellfish. 
This work was funded by the European Regional Development Fund Interreg IVA Program as part of the collaborative project AquaManche, a PhD grant from Ifremer and the Brittany Region, and a studentship grant from Cap Atlantique. We thank Cap Atlantique and the Ifremer coastal laboratories (Laboratoires Environnement - Ressources) for the shellfish collection. In addition, we acknowledge C. Le Mennec, C. Marin and E. Troadec from RBE- EMP - MIC/LNR, Ifremer, for their help with dissecting the shellfish, Dr. H. McCombie-Boudry for revising the quality of the English and J.P. Furet from INRA Jouy-en-Josas for his valuable input on the selection of the protocols tested.

\section{References}

Baker-Austin, C., Rangdale, R., Lowther, J., Lees, D. N., 2010. Application of mitochondrial DNA analysis for microbial source tracking purposes in shellfish harvesting waters. Water Sci. Technol. 61, 1-7.

Ballesté, E., Blanch, A. R., 2010. Persistence of Bacteroides Species Populations in a River as Measured by Molecular and Culture Techniques Appl. Environ. Microbiol. 76, 7608-7616.

Burkhardt, W., Calci, K., 2000. Selective accumulation may account for shellfish-associated viral illness. Appl. Environ. Microbiol. 66, 1375-1378.

Delmas, G., Jourdan Da Silva, N., Pihier, N., Weill, F., Vaillant, V., de Valk, H., 2010. Foodborne outbreaks in France between 2006 and 2008. Bulletin Epidémiologique Hebdomadaire. 31$32,344-348$.

Dick, L. K., Bernhard, A. E., Brodeur, T. J., Santo Domingo, J. W., Simpson, J. M., Walters, S. P., Field, K. G., 2005. Host distribution of uncultivated fecal Bacteroidales bacteria reveal genetic markers for fecal source identification. Appl. Environ. Microbiol. 71, 3184-3191.

Dore, W. J., Lees, D. N., 1995. Behavior of Escherichia coli and male-specific bacteriohage in environmentally contaminated bivalve mollusks before and after depuration. Appl. Environ. Microbiol. 61, 2830-2834.

European Parliament and Council, The organisation of official controls on products of animal origin intended for human consumption. Vol. Regulation (EC) No 854/2004. Official Journal of the European Union, 2004, pp. 83-127.

Gourmelon, M., Caprais, M. P., Le Mennec, C., Mieszkin, S., Ponthoreau, C., Gendronneau, M., 2010. Application of library-independent microbial source tracking methods for identifying the sources of faecal contamination in coastal areas. Water Sci. Technol. 61, 1401-1409.

Gourmelon, M., Montet, M. P., Lozach, S., Le Mennec, C., Pommepuy, M., Beutin, L., VernozyRozand, C., 2006. First isolation of Shiga toxin 1d producing Escherichia coli variant strains in shellfish from coastal areas in France. J. Appl. Microbiol. 100, 85-97.

ISO, Microbiology of Food and Animal Feeding Stuffs. Horizontal Method for the Enumeration of Beta-glucurosidase-positive Escherichia coli. Part 3: Most Probable Number Technique 
Using 5-Bromo-4-chloro-3-indolyl-beta-D-glucuronide. In: International Standardization Organization, (Ed.), ISO/TS 16649-3, Geneva, Switzerland, 2005.

Kaufman, G., Blackstone, G., Vickery, M., Bej, A., Bowers, J., Bowen, M., Meyer, R., DePaola, A., 2004. Real-time PCR quantification of Vibrio parahaemolyticus in oysters using an alternative matrix. J. Food Prot. 67, 2424-2429.

Kueh, C. S. W., Chan, K.-Y., 1985. Bacteria in bivalve shellfish with special reference to the oyster. J. Appl. Bacteriol. 1985, 41-47.

Lawson, P. A., Collins, M. D., Falsen, E., Foster, G., 2006. Catellicoccus marimammalium gen. nov., sp. nov., a novel Gram-positive, catalase-negative, coccusshaped bacterium from porpoise and grey seal. Int. J. Syst. Evol. Microbiol. 56, 429-432.

Le Guyader, F. S., Parnaudeau, S., Schaeffer, J., Bosch, A., Loisy, F., Pommepuy, M., Atmar, R. L., 2008. Detection and Quantification of Noroviruses in Shellfish. Appl. Environ. Microbiol. $75,618-624$.

Ley, V., Higgins, J., Fayer, R., 2002. Bovine enteroviruses as indicators of fecal contamination. Appl. Environ. Microbiol. 68, 3455-3461.

Lowther, J. A., Henshilwood, K., Lees, D. N., 2008. Determination of Norovirus Contamination in Oysters from Two Commercial Harvesting Areas over an Extended Period, Using Semiquantitative Real-Time Reverse Transcription PCR. J. Food Prot. 71, 1427-1433.

Lu, J., Santo Domingo, J. W., Lamendella, R., Edge, T., Hill, S., 2008. Phylogenetic Diversity and Molecular Detection of Bacteria in Gull Feces. Appl. Environ. Microbiol. 74, 3969-3976.

Luan, C., Levin, R. E., 2008. Use of activated carbon coated with bentonite for increasing the sensitivity of pcr detection of Escherichia coli O157:H7 in Canadian oyster (Crassostrea gigas) tissue. J. Microbiol. Methods. 72, 67-72.

Maalouf, H., Zakhour, M., Le Pendu, J., Le Saux, J.-C., Atmar, R. L., Le Guyader, F. S., 2010. Distribution in Tissue and Seasonal Variation of Norovirus Genogroup I and II Ligands in Oysters. Appl. Environ. Microbiol. 76, 5621-5630.

Mauffret, A., Caprais, M.-P., Gourmelon, M., 2012. Relevance of Bacteroidales and F-specific RNA bacteriophages for efficient fecal contamination tracking at the level of a catchment in France. Appl. Environ. Microbiol. 78, doi:10.1128/AEM.00315-12.

Mieszkin, S., Furet, J. P., Corthier, G., Gourmelon, M., 2009a. Estimation of Pig Fecal Contamination in a River Catchment by Real-Time PCR Using Two Pig-Specific Bacteroidales 16S rRNA Genetic Markers. Appl. Environ. Microbiol. 75, 3045-3054.

Mieszkin, S., Furet, J. P., Gérard, C., Pommepuy, M., Le Saux, J. C., Bougeard, M., Hervio-Heath, D., Gourmelon, M., Discrimination between human, pig and ruminant faecal contaminations in a river catchment by real-time PCR using host-specific markers. 7th International Conference on Molluscan Shellfish Safety (ICMSS), Nantes, France, 2009b, pp. 1-7. 
Mieszkin, S., Yala, J. F., Joubrel, R., Gourmelon, M., 2010. Phylogenetic analysis of Bacteroidales 16S rRNA gene sequences from human and animal effluents and assessment of ruminant faecal pollution by real-time PCR. J. Appl. Microbiol. 108, 974-984.

Morrison, C. M., Dial, S. M., Day, W. A., Joens, L. A., 2012. Investigations of Salmonella enterica Serovar Newport Infections of Oysters by Using Immunohistochemistry and Knockout Mutagenesis. Appl. Environ. Microbiol. 78, 2867-2873.

Nordstrom, J. L., Vickery, M. C. L., Blackstone, G. M., Murray, S. L., DePaola, A., 2007. Development of a multiplex real-time PCR assay with an internal amplification control for the detection of total and pathogenic Vibrio parahaemolyticus bacteria in oysters. Appl. Environ. Microbiol. 73, 5840-5847.

Panicker, G., Vickery, M. C. L., Bej, A. K., 2004. Multiplex PCR detection of clinical and environmental strains of Vibrio vulnificus in shellfish. Can. J. Microbiol./Rev. Can. Microbiol. $50,911-922$.

Perkins, O. F., Haven, D. S., Morales-Alam, R., Rhodes, M. W., 1980. Uptake and elimination of bacteria in shellfish. J. Food Prot. 43, 124-126.

Pina, S., Puig, M., Lucena, F., Jofre, J., Girones, R., 1998. Viral pollution in the environment and in shellfish: Human adenovirus detection by PCR as an index of human viruses. Appl. Environ. Microbiol. 64, 3376-3382.

Reischer, G. H., Haider, J. M., Sommer, R., Stadler, H., Keiblinger, K. M., Hornek, R., Zerobin, W., Mach, R. L., Farnleitner, A. H., 2008. Quantitative microbial faecal source tracking with sampling guided by hydrological catchment dynamics. Environ. Microbiol. 10, 2598-2608.

Roslev, P., Bukh, A. S., Iversen, L., Sønderbo, H., Iversen, N., 2010. Application of mussels as biosamplers for characterization of faecal pollution in coastal recreational waters. Water Sci. Technol. 62, 586-593.

Roslev, P., Iversen, L., Sonderbo, H. L., Iversen, N., Bastholm, S., 2009. Uptake and persistence of human associated Enterococcus in the mussel Mytilus edulis: relevance for faecal pollution source tracking. J. Appl. Microbiol. 107, 944-953.

Savichtcheva, O., Okayama, N., Ito, T., Okabe, S., 2005. Application of a direct fluorescencebased live/dead staining combined with fluorescence in situ hybridization for assessment of survival rate of Bacteroides spp. in drinking water. Biotechnol. Bioeng. 92, 356-363.

Seurinck, S., Defoirdt, T., Verstraete, W., Siciliano, S. D., 2005. Detection and quantification of the human-specific HF183 Bacteroides 16S rRNA genetic marker with real-time PCR for assessment of human faecal pollution in freshwater. Environ. Microbiol. 7, 249-259.

Shanks, O. C., Nietch, C., Simonich, M., Younger, M., Reynolds, D., Field, K. G., 2006. Basin-wide analysis of the dynamics of fecal contamination and fecal source identification in Tillamook Bay, Oregon. Appl. Environ. Microbiol. 72, 5537-5546.

Shieh, Y., Baric, R., Woods, J., Calci, K., 2003. Molecular surveillance of enterovirus and norwalklike virus in oysters relocated to a municipal-sewage-impacted gulf estuary. Appl. Environ. Microbiol. 69, 7130-7136. 
van der Wielen, P. W. J. J., Medema, G., 2010. Unsuitability of Quantitative Bacteroidales 16S rRNA Gene Assays for Discerning Fecal Contamination of Drinking Water. Appl. Environ. Microbiol. 76, 4876-4881.

Vantarakis, A., Komninou, G., Venieri, D., Papapetropoulou, M., 2000. Development of a multiplex PCR detection of Salmonella spp. and Shigella spp. in mussels. Lett. Appl. Microbiol. 31, 105-109.

Wang, D. P., Zhang, D. D., Chen, W. Y., Yu, S. J., Shi, X. M., 2010. Retention of Vibrio parahaemolyticus in oyster tissues after chlorine dioxide treatment. Int. J. Food Microbiol. 137, 76-80.

Wolf, S., Hewitt, J., Greening, G. E., 2010. Viral Multiplex Quantitative PCR Assays for Tracking Sources of Fecal Contamination. Appl. Environ. Microbiol. 76, 1388-1394.

\section{Tables}

Table 1. Design of the microbial analysis of artificially contaminated and field collected shellfish.

\begin{tabular}{|c|c|c|c|c|}
\hline $\begin{array}{l}\text { Experiment } \\
\text { Conditions }\end{array}$ & Bacterial analysis & Sample & $\begin{array}{l}\text { Bacterial } \\
\text { extraction kit }\end{array}$ & $\begin{array}{l}\text { Sample nb. per experiment } \\
\text { (Extraction nb. per sample) }\end{array}$ \\
\hline \multicolumn{5}{|c|}{ Artificially contaminated samples } \\
\hline \multicolumn{5}{|l|}{ Experiment 1} \\
\hline Control & E. coli; & IL & FastDNA & $n=1(3 \mathrm{C}, 6 \mathrm{~A})$ \\
\hline Pig feces & AllBac; & DT & DNAZOL & $n=1(3 \mathrm{C}, 6 \mathrm{~A})$ \\
\hline \multirow[t]{4}{*}{$72 \mathrm{~h}, 15^{\circ} \mathrm{C}$} & Pig1Bac & DT & FastDNA & $n=1(3 \mathrm{C}, 6 \mathrm{~A})$ \\
\hline & & DT & STOOL & $n=1(3 \mathrm{C}, 6 \mathrm{~A})$ \\
\hline & & DT & MagMax & $n=1(3 \mathrm{C}, 6 \mathrm{~A})$ \\
\hline & & SW & Mini kit & $n=1(3 \mathrm{C}, 6 \mathrm{~A})$ \\
\hline \multicolumn{5}{|l|}{ Experiment 2} \\
\hline Control & E. coli; & IL & FastDNA & $n=1(3)$ \\
\hline WWTP influent & AllBac; & DT & DNAZOL & $n=1(3)$ \\
\hline \multirow[t]{2}{*}{$24 \mathrm{~h}, 19-21^{\circ} \mathrm{C}$} & HF183 & SF & DNAZOL & $n=1(3)$ \\
\hline & & SW & Mini kit & $n=1(3)$ \\
\hline \multicolumn{5}{|l|}{ Experiment 3} \\
\hline Control & E. coli; & IL & FastDNA & $n=1(3)$ \\
\hline Cow pat & AllBac; & DT & DNAZOL & $n=1(3)$ \\
\hline \multirow[t]{2}{*}{$24 \mathrm{~h}, 19-21^{\circ} \mathrm{C}$} & Rum2Bac & SF & DNAZOL & $n=1(3)$ \\
\hline & & SW & Mini kit & $n=1(3)$ \\
\hline \multicolumn{5}{|l|}{ Experiment 4} \\
\hline Control & E. coli; & IL & FastDNA & $n=1(3)$ \\
\hline C. marimammalium & C. marim; & DT & DNAZOL & $n=1(3)$ \\
\hline \multirow{2}{*}{$24 \mathrm{~h}, 19-21^{\circ} \mathrm{C}$} & Gull2 & SF & DNAZOL & $n=1(3)$ \\
\hline & & SW & Mini kit & $n=1(3)$ \\
\hline \multirow{2}{*}{\multicolumn{5}{|c|}{ Field collected samples }} \\
\hline & & & & \\
\hline \multirow[t]{3}{*}{$n=38$ batches } & E. coli; & IL & FastDNA & $n=38(1$ or 2$)$ \\
\hline & AllBac; & DT & DNAZOL & $n=24(1$ or 2$)$ \\
\hline & $\begin{array}{l}\text { HF1 } 183 \text { or Hum1Bac; } \\
\text { Rum2Bac; } \\
\text { Pig2Bac }\end{array}$ & SF & DNAZOL & $n=1(2)$ \\
\hline \multicolumn{5}{|l|}{ Cockles and clams } \\
\hline$n=22$ batches & E. coli; & IL & FastDNA & $n=22(1,2$ or 3$)$ \\
\hline & AllBac; & DT & DNAZOL & $n=20(1,2$ or 3$)$ \\
\hline & $\begin{array}{l}\text { HF183; } \\
\text { Rum2Bac }\end{array}$ & $\mathrm{SF}$ & DNAZOL & $n=7(2$ or 3$)$ \\
\hline
\end{tabular}

SW: seawater, IL: intravalvular liquid, DT: digestive tissues; SF: total shellfish flesh (including shellfish flesh and intravalvular liquid); nb.: number; C: control microcosm, A: artificially contaminated microcosm; *: one sample is a homogenate of 12 oysters or 30 cockles or 30 clams 
Table 2. Real-time PCR marker quantification in tissue samples from field samples of oysters, cockles or clams

$\begin{array}{ccccccc}\text { Sample } & \begin{array}{l}\text { Bacterial DNA } \\ \text { extraction kit }\end{array} & \text { Marker } & \begin{array}{c}\text { \% Q samples } \\ (\mathrm{nb} \text { Q/nb. } \\ \text { Tot })^{1}\end{array} & \begin{array}{c}\text { Min-Max } \\ \text { Q Level }\end{array} & \begin{array}{c}\text { Min-Max } \\ \text { LOQ Level Q Level-LOQ Level }{ }^{2}\end{array} & \text { Unit } \\ & & & \end{array}$

Oysters [3.1 \pm 0.5 (min-max: 1.7- 3.9) MPN E. coli $100 \mathrm{~g} \mathrm{SF}^{-1} ; 38$ batches]

\begin{tabular}{|c|c|c|c|c|c|c|c|}
\hline IL & FastDNA & AllBac & $95 \%(36 / 38)$ & $1.6-4.3$ & $1.2-2.2$ & $1.6 \pm 0.8$ & $\log$ copies $m L^{-1} \mathrm{IL}$ \\
\hline IL & FastDNA & Pig2Bac & $\mathbf{0 \%}(0 / 18)$ & $<\mathrm{LOQ}$ & $1.2-2.2$ & $<\mathrm{LOQ}$ & $\log$ copies $\mathrm{mL}^{-1} \mathrm{IL}$ \\
\hline IL & FastDNA & HF183 or Hum1Bac & $\mathbf{3 1 \%}(11 / 36)$ & $1.4-2.7$ & $1.2-2.2$ & $0.8 \pm 0.4$ & $\log$ copies $\mathrm{mL}^{-1} \mathrm{IL}$ \\
\hline IL & FastDNA & Rum2Bac & $23 \%(8 / 35)$ & $1.5-2.5$ & $1.2-2.2$ & $0.7 \pm 0.3$ & $\log$ copies $\mathrm{mL}^{-1} \mathrm{IL}$ \\
\hline DT & DNAZOL & AllBac & $\mathbf{4 2 \%}(10 / 24)$ & $3.3-5.5$ & $3.0-4.0$ & $0.8 \pm 0.3$ & $\log$ copies $\mathrm{g}^{-1} \mathrm{DT}$ \\
\hline DT & DNAZOL & Pig2Bac & $\mathbf{0 \%}(0 / 18)$ & $<\mathrm{LOQ}$ & $3.0-4.0$ & $<$ LOQ & $\log$ copies $\mathrm{g}^{-1} \mathrm{DT}$ \\
\hline DT & DNAZOL & HF183 & $\mathbf{0 \%}(0 / 23)$ & $<\mathrm{LOQ}$ & $3.0-4.0$ & $<\mathrm{LOQ}$ & $\log$ copies $\mathrm{g}^{-1} \mathrm{DT}$ \\
\hline DT & DNAZOL & Rum2Bac & $\mathbf{0 \%}(0 / 20)$ & $<\mathrm{LOQ}$ & $3.0-4.0$ & $<$ LOQ & $\log$ copies $g^{-1} \mathrm{DT}$ \\
\hline SF & DNAZOL & AllBac & $100 \%(1 / 1)$ & 4.7 & 3.6 & 1.1 & $\log$ copies $100 \mathrm{~g}^{-1} \mathrm{SF}$ \\
\hline SF & DNAZOL & HF183 & 0\% $(0 / 1)$ & $<\mathrm{LOQ}$ & 3.6 & $<\mathrm{LOQ}$ & $\log$ copies $100 \mathrm{~g}^{-1} \mathrm{SF}$ \\
\hline SF & DNAZOL & Rum2Bac & $\mathbf{0 \%}(0 / 1)$ & $<\mathrm{LOQ}$ & 3.6 & $<$ LOQ & $\log$ copies $100 \mathrm{~g}^{-1} \mathrm{SF}$ \\
\hline
\end{tabular}

Cockles or clams [3.4 \pm 0.7 (min-max: 2.7- 4.9) MPN E. coli/ $100 \mathrm{~g}$ SF; 22 batches]

\begin{tabular}{|c|c|c|c|c|c|c|c|}
\hline IL & FastDNA & AllBac & $45 \%(10 / 22)$ & $1.3-4.2$ & $1.2-2.2$ & $1.2 \pm 0.7$ & $\log$ copies $\mathrm{mL}^{-1} \mathrm{IL}$ \\
\hline IL & FastDNA & HF183 & $\mathbf{0 \%}(0 / 5)$ & $<$ LOQ & $1.2-2.2$ & $<$ LOQ & $\log$ copies $\mathrm{mL}^{-1} \mathrm{IL}$ \\
\hline IL & FastDNA & Rum2Bac & $\mathbf{0 \%}(0 / 8)$ & $<\mathrm{LOQ}$ & $1.2-2.2$ & $<\mathrm{LOQ}$ & $\log$ copies $\mathrm{mL}^{-1} \mathrm{IL}$ \\
\hline DT & DNAZOL & AllBac & $60 \%(12 / 20)$ & $3.1-5.8$ & $3.0-5.0$ & $1.0 \pm 0.5$ & $\log$ copies $\mathrm{g}^{-1} \mathrm{DT}$ \\
\hline DT & DNAZOL & HF183 & $\mathbf{0 \%}(0 / 9)$ & $<$ LOQ & $3.0-5.0$ & $<$ LOQ & $\log$ copies $\mathrm{g}^{-1} \mathrm{DT}$ \\
\hline DT & DNAZOL & Rum2Bac & $\mathbf{0 \%}(0 / 10)$ & $<\mathrm{LOQ}$ & $3.0-5.0$ & $<\mathrm{LOQ}$ & $\log$ copies $\mathrm{g}^{-1} \mathrm{DT}$ \\
\hline SF & DNAZOL & AllBac & $86 \%(6 / 7)$ & $4.8-5.4$ & $3.4-4.4$ & $1.2 \pm 0.4$ & $\log$ copies $100 \mathrm{~g}^{-1} \mathrm{SF}$ \\
\hline SF & DNAZOL & HF183 & $\mathbf{0 \%}(0 / 6)$ & $<\mathrm{LOQ}$ & $3.6-6.3$ & $<$ LOQ & $\log$ copies $100 \mathrm{~g}^{-1} \mathrm{SF}$ \\
\hline SF & DNAZOL & Rum2Bac & $\mathbf{0 \%}(0 / 6)$ & $<\mathrm{LOQ}$ & $3.6-6.3$ & $<\mathrm{LOQ}$ & $\log$ copies $100 \mathrm{~g}^{-1} \mathrm{SF}$ \\
\hline
\end{tabular}

Q: quantified samples; Tot: total samples analyzed; IL: intravalvular liquid; DT: digestive tissues; SF: total shellfish flesh

1: one sample is a homogenate of 12 oysters of oyster or 30 cockles or 30 clams and 1 to 3 DNA extraction replicates were performed per sample

${ }^{2}$ : mean difference between i) PCR marker concentrations in quantified samples, and ii) the limit of quantification (LOQ) 
Table 3. Sample dilution for PCR analysis.

\begin{tabular}{|c|c|c|c|c|}
\hline \multirow[t]{2}{*}{ Sample } & \multirow{2}{*}{$\begin{array}{l}\text { Bacterial DNA } \\
\text { extraction kit }\end{array}$} & \multicolumn{3}{|c|}{ Number of sample } \\
\hline & & Total & Not diluted & Diluted ( $\geq 10$-fold) ${ }^{*}$ \\
\hline \multicolumn{5}{|c|}{ Artificially contaminated oyster batches } \\
\hline IL & FastDNA & 4 & 2 & 2 (up to 10$)$ \\
\hline DT & DNAZOL & 4 & 2 & $2($ up to 100$)$ \\
\hline DT & FastDNA & 1 & 0 & $1($ up to 100$)$ \\
\hline DT & MAGMAX & 1 & 0 & $1($ up to 100$)$ \\
\hline DT & STOOL & 1 & 0 & $1($ up to 10$)$ \\
\hline SF & DNAZOL & 3 & 2 & $1($ up to 10$)$ \\
\hline \multicolumn{5}{|c|}{ Naturally contaminated oyster batches } \\
\hline IL & FastDNA & 38 & 27 & 11 (up to 100$)$ \\
\hline DT & DNAZOL & 24 & 2 & $22($ up to 10$)$ \\
\hline SF & DNAZOL & 1 & 1 & 0 \\
\hline \multicolumn{5}{|c|}{ Naturally contaminated cockle and clam batches } \\
\hline IL & FastDNA & 22 & 10 & 12 (up to 100$)$ \\
\hline DT & DNAZOL & 20 & 8 & 12 (up to 10$)$ \\
\hline $\mathrm{SF}$ & FastDNA & 7 & 3 & 4 (up to 10$)$ \\
\hline
\end{tabular}

*: Number of samples for which one at least one of the DNA extraction replicates was diluted 10 -fold or more. The highest dilution employed is indicated in parentheses. 
Figure 1. E. coli and C. marimammalium concentrations in seawater and oysters at the start of the experiment, t0, and at the end, t end, after 24-h, (experiments 2, 3 and 4) or 72-h (experiment 1) exposure in artificially contaminated microcosms. NT : not tested

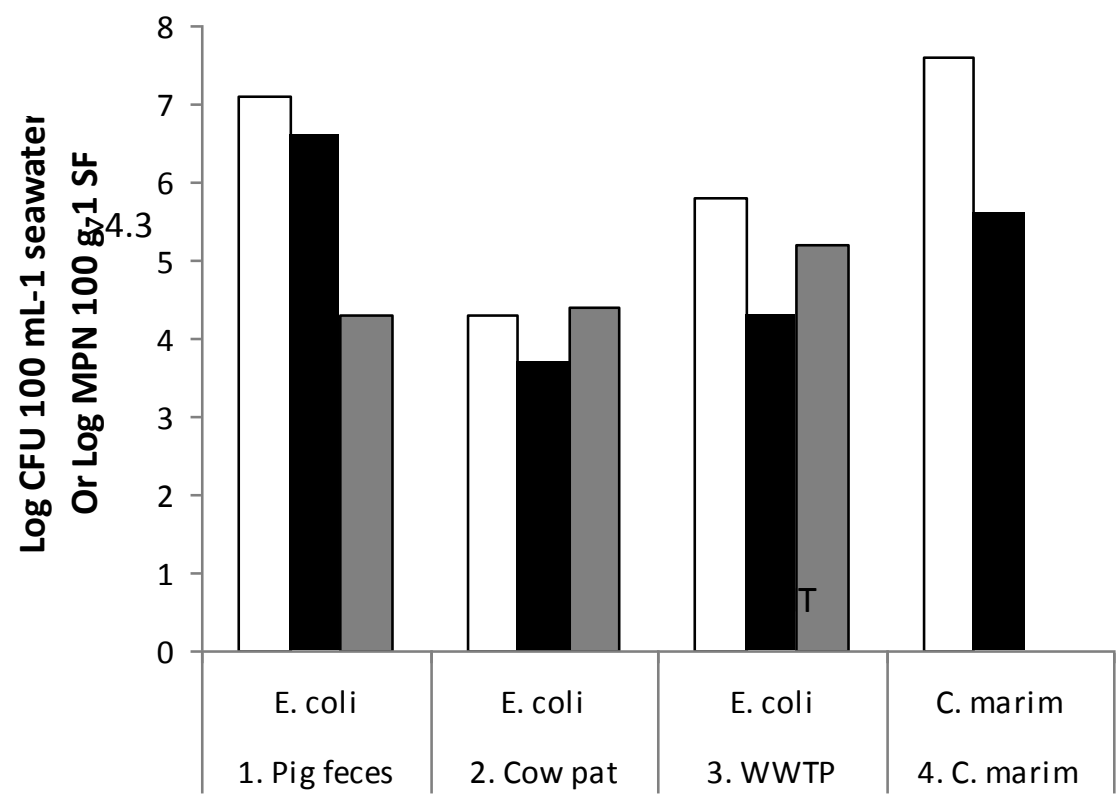

$\square$ Water t0 $\quad$ Water t end $\quad \square$ Shellfish (MPN 100 g-1 SF)

Figure 2. Real-time PCR marker concentrations in seawater in the artificial contamination experiments (Experiments 1-4). Numbers of extraction replicates quantified over the total tested are indicated at the tops of the columns.

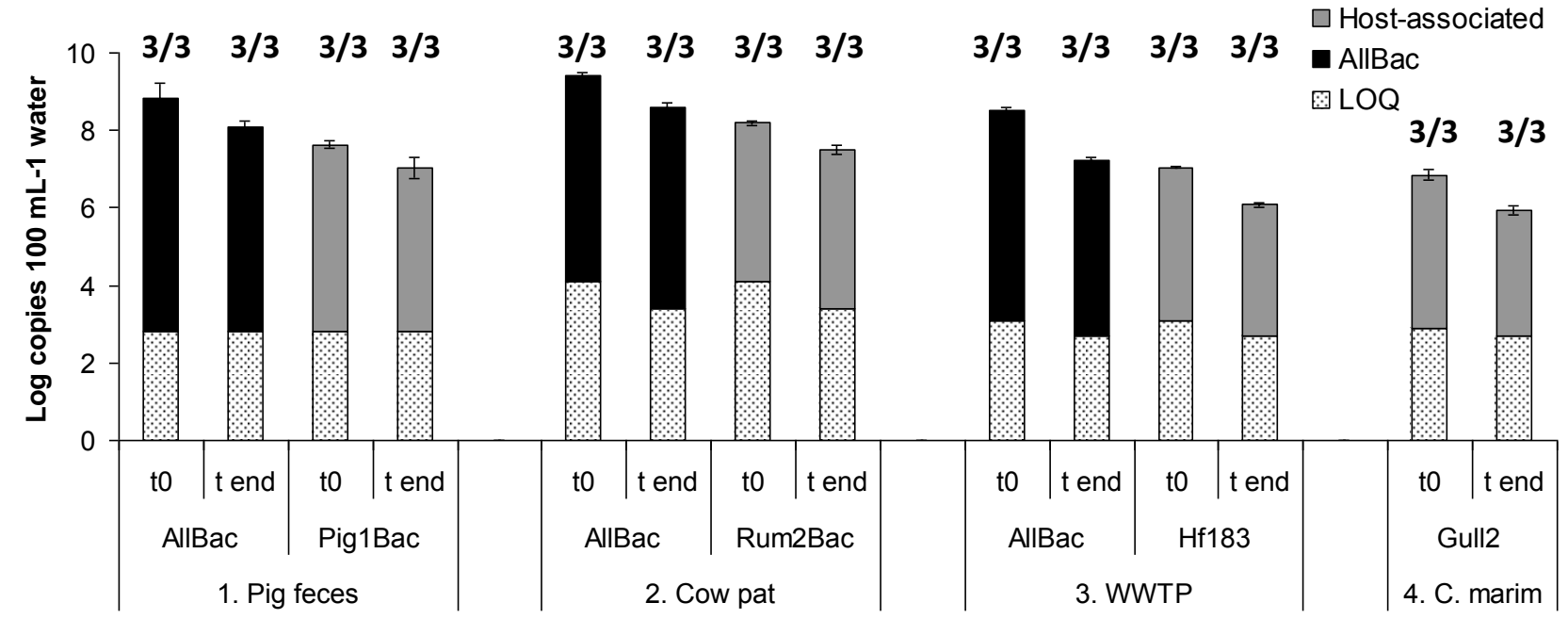

LOQ: Limit of quantification 
Figure 3. Real-time PCR marker concentrations in oysters in the artificial contamination experiments based on different DNA extraction methods on different tissues. Numbers of extraction replicates quantified over the total tested are indicated at the tops of the columns.

\section{A. Intravalvular liquid}

웅 LOQ 国 LOQ 2 AllBac $\square$ HostAssociated

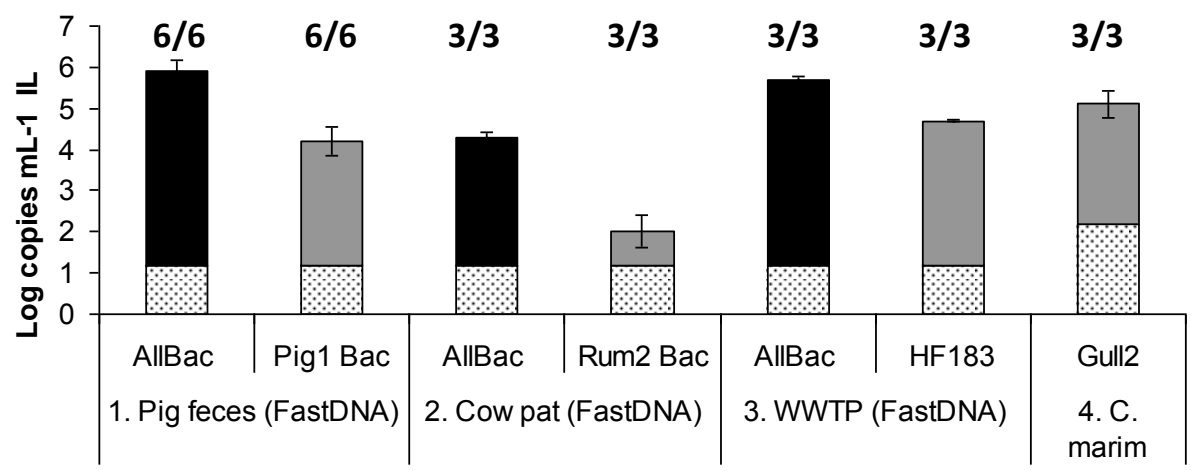

\section{B. Digestive tissues}

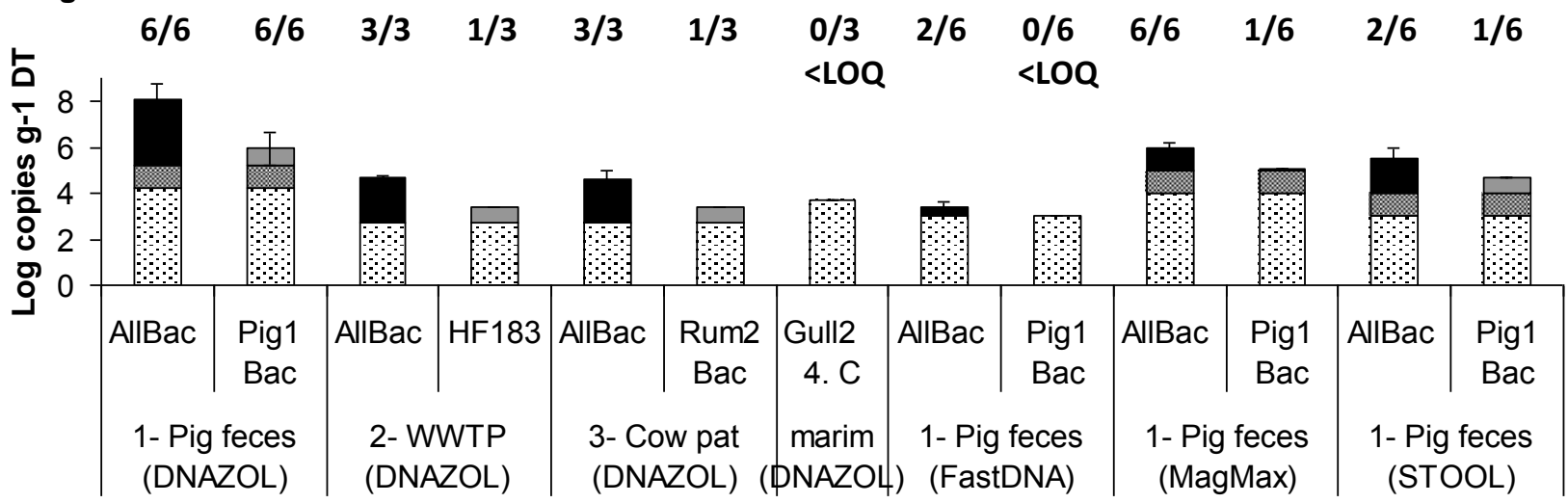

\section{Total shellfish flesh}

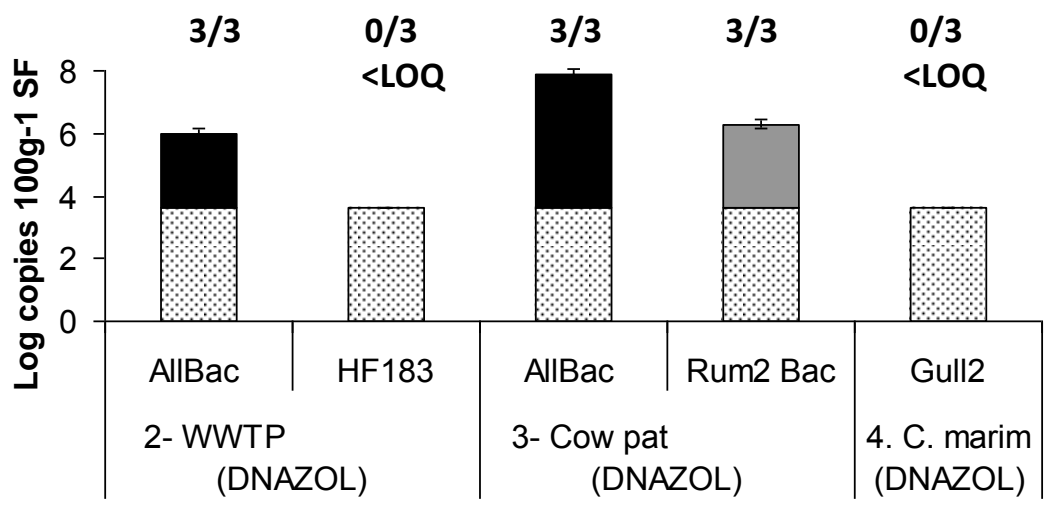

LOQ 1 and 2: Limits of quantification used according to the dilution of the DNA extracts prior to PCR runs (1-, 10- or 100-fold). 